\title{
Effect of Ginseng (Panax ginseng) against Testicular Toxicity Induced by Sodium Valproate in Male Rats
}

\author{
Lobna A. Shelbaya
}

Department of Home Economics, Faculty of Specific Education, Mansoura University, Egypt

\section{ABSTRACT}

$T$

he aim of this experimental study was to investigate the effects of ginseng powder, extract, L-carnitine and their combination against sodium valproate induced testicular toxicity in rats, the reproductive performance of male rats with respect to semen parameters, male sex hormones and the testicular antioxidant system. A total of forty two mature male albino rats were divided into six groups of seven rats. The control group received saline, whereas the other five groups received sodium valproate the firs represented positive group, after that four groups received ginseng (100 mg/kg. diet), ginseng extract (10 mg/kg. B wt /rat), Lcarnitine (150 mg/kg Bwt/rat /day) or a combination of both ginseng and Lcarnitine via a stomach tube daily respectively for one month. At the end of the treatment period, rats were sacrificed, weights of sexual organ recorded and their sperm characteristics count, antioxidant enzyme factors levels (reduced glutathione, malondialdehyde, superoxide dismutase and total antioxidant capacity) and sex hormone levels (testosterone, Follicle stimulating hormone (FSH) and luteinizing hormone (LH) were analyzed. Results showed that the four experimental treatments improved lipid parameters, liver function, sperm parameters, antioxidant enzyme activity and testosterone hormone levels; the most pronounced positive effects were observed in the group that received a combination of both ginseng and Lcarnitine. Therefore, the administration of a combination of ginseng and Lcarnitine may be beneficial for improving male sexual performance.

Keywords: Ginseng - L-Carnitine - Sodium Valproate - Rats. 


\section{INTRODUCTION}

\section{Ginseng}

(Panax

ginseng) has been used not only as a medicine but also as a restorative and prophylactic remedy for thousands of years in Asia. (Christensen, 2009) ginseng is classified as fresh ginseng (raw ginseng). Ginsenosides are the most studied active components in ginseng. About 40 types of ginsenosides are contained in ginseng along with nonsaponin compounds like acidic polysaccharides and polyacetylenes, (Sun, 2011). Much basic research on the range of efficacies of ginseng, including its immuneenhancing, anti-fatigue, and anti-cancer functions and improvements to cardiovascular function, is ongoing, along with numerous studies on its mechanisms, (Liu,et al. 2007).

Ginseng is constituted of organic (80\%-90\%) and inorganic substances (approximately 10\%) and contain a number of active constituents, such as saponins or nitrogenous substances, essential oils, ginsenosides, phytosterol, carbohydrates, organic acids, peptides, vitamins, amino acids and minerals (Xie, et al. 2005). Therefore, it is necessary to evaluate the efficacy and safety of ginseng along with the increased consumption of ginseng as a functional food or complementary medicine (Shergis, et al. 2013). The anti-inflammatory activity, effects on pulmonary function and erectile dysfunction, improvement of cognition in patients with Alzheimer's disease and sexual arousal in menopausal women as well as cancer prevention using ginseng will be discussed (Shun, 2010). Recently, the consumption of ginseng has increased greatly, and a variety of ginseng products have been developed and manufactured in many countries. its major physiologically active ingredients include alkaloids, ginsenosides, polysaccharides, amino acids, polyacetylenes, and phenolic compounds. Ginseng is known to affect various tissues including 
nervous, endocrine, and cardiovascular and immune system tissues (Attele, et al., $\begin{array}{lllll}1 & 9 & 9 & 9 & \text {. }\end{array}$

L-carnitine is a conditionally essential amino acid which plays an important role as a cofactor in cellular energy production in the mitochondrial system. Lcarnitine needed for the oxidation of long-chain fatty acids in the mitochondria of all cells (Foster, 2004). Lcarnitine exhibits a wide range of biological activities including anti-inflammatory, neuroprotective properties, cardioprotective, antiapoptotic and gastroprotective, (Onem, et al. 2006).

Mechanisms of toxicity of sodium valproate on male reproduction and spermatogenesis were attributed to its direct cytotoxic effect on testis and indirectly decreasing level of testosterone, FSH and $\mathrm{LH}$ in serum (Bairy et al. 2010). Moreover, Sodium valproate induced oxidative stress and reproductive toxicity in male rats.

\section{MATERIAL \& METHOD}

\section{Material and chemicals:}

Ginseng (Panax ginseng):

Ginseng roots were obtained from the Agricultural Research Center, Dokki, Giza, Egypt.

\section{Drugs and chemicals:}

L-Carnitine ${ }^{\odot}$ : The required volume of L-carnitine was diluted in the appropriate volume of saline to obtain the calculated dose.

Sodium valproate ${ }^{\odot}$ : It is one of products of SanofiSynthelaboo Company, France, obtained as oral solution sold under trade name Depakin.

Kits: Kits used to determine serum uric acid, urea, creatinine, alanine and aspartate aminotransferases (ALT, AST), Alkaline phosphatase (ALP), cholesterol, triglycerides, high density lipoproteins cholesterol (HDL), low density lipoproteins cholesterol (LDL), testosterone, follicle stimulating hormone level (FSH), and luteinizing 
hormone (LH), superoxide dismutase (SOD), total antioxidants and malondialdehyde produced by Egyptian American Company for laboratory Service and Supplied by Alkan Company. Animals: The animals were obtained from Laboratory of Animal Colony, Helwan, Egypt.

\section{Experimental Animals}

A total of forty two apparently healthy adult male albino rats that initially weighed approximately $115 \pm 5$ $\mathrm{g}$ were used for the experiments. The animals were allocated in plastic cages with metallic stainless covers. Rats were fed the basal diet for 7 days before the beginning of the experiment for adaptation. The standard diet comprised of casein $(200 \mathrm{~g} / \mathrm{kg})$, corn starch $(497 \mathrm{~g} / \mathrm{kg})$, sucrose $(100 \mathrm{~g} / \mathrm{kg})$, cellulose $(30 \mathrm{~g} / \mathrm{kg})$, corn oil $(50 \mathrm{~g} / \mathrm{kg})$, minerals mixture $(100 \mathrm{~g} / \mathrm{kg})$, vitamins mixture $(20 \mathrm{~g} / \mathrm{kg})$ and DL-methionine $(3 \mathrm{~g} / \mathrm{kg})$ prepared according to, (Reeves, et al. 1993). Animals were subjected to a 12 hours light and 12 hours dark schedule.

\section{Methods:}

\section{Preparation of ginseng roots} extract: was prepared daily as tea by steeping in boiling water and steeping for 5 minutes. It was given to rats at dose $(10 \mathrm{mg} / \mathrm{kg} \mathrm{Bwt} / \mathrm{rat})$.

Scavenging effect on 2, 2diphenyl-1-picrylhydrazyl (DPPH) radicals:

The effect of ginseng on DPPH radical was studied, employing the modified method described earlier by (Yamaguchi, et al. 1998). Briefly, $1.5 \mathrm{ml}$ of DPPH solution $(0.1 \mathrm{mM}$, in $95 \%$ Ethanol)was incubated with varying concentrations of the extract (ginseng, 0.75 - 5.0 $\mathrm{mg}$ ). The reaction mixture was shaken well and incubated for $20 \mathrm{~min}$ at room temperature and the absorbance of the resulting solution was read at $517 \mathrm{~nm}$ a gains a blank. The radical scavenging activity was measured as a decrease in the absorbance of DPPH and was calculated using the following equation: 
Scavenging effect $\%=$ 1- A Sample $(517 \mathrm{~nm}) \times 100 / \mathrm{A}$ Control (517nm)

\section{HPLC analysis of} polyphenols and flavonoids:

HPLC analysis of extracts was performed using an Agilent 1200 chromatograph equipped with a PDA model G1315B, a Bin pump model G1312A, an autosampler model G1313A and a RR Zorbax Eclipse Plus C18 column (1.8 $\mu \mathrm{m}, 150$ $\mathrm{mm} \times 4.6 \mathrm{~mm})$. The mobile phase A was $0.2 \%$ formic acid in water and the mobile phase $\mathrm{B}$ was acetonitrile. Elution was performed at $0.95 \mathrm{~mL}$ min-1 with the following gradient program of solvent B: $0-20$ min, 5-16 \%; 20-28 min, 16$40 \%$; 28-32 min, 40-70\%; 32-36 min, 70-99 \%; 36-45 min, $99 \%$ and 45-46, min. 99-5 \%.30 The injection volume was $10 \mu \mathrm{L}$. Wavelengths of $280 \mathrm{~nm}$ (for flavanols and benzoic acid derivatives) and $360 \mathrm{~nm}$ (for flavonols and cinnamic acid derivatives) were selected for detection according to (Merfort, et al. 1997).

\section{Experimental Design}

A total of forty two rats were designated into four groups (7 rats each). The control group received saline, whereas the second group received sodium valproate in dose $500 \mathrm{mg} / \mathrm{kg}$ to induce testicular injury (Bairy, et al. 2010). The first group was positive control. The other four groups received ginseng powder $(100 \mathrm{mg} / \mathrm{kg} /$ day $)$, ginseng extract $(10 \mathrm{mg} / \mathrm{kg})$, Carnitine $(150 \mathrm{mg} / \mathrm{kg} /$ day $)$, according to (Mohamed and Farghaly, 2009), and their combination of ginseng powder, extract and Lcarnitine, daily via a stomach tube for one month.

\section{Biochemical analysis of} serum:

Uric acid was determined in the serum according to the method described by (Patton and Crouch, 1977). Urea was determined according to( Han, et al. 1984). Creatinine was determined according to (Bartels, et al. 1972). Aspartate amino transferase (AST) and Alanine amino transferase (ALT) were 
assayed by (Reitman and Frankel, 1957). Alkaline phosphatase (ALP) was assayed by (Kind and King, 1954). Serum total cholesterol, triglycerides, high density lipoprotein and low density lipoprotein were determined by the methods of (Roeschlau, et al. 1974) and (Fossati and Prencipel, 1982), respectively. Biochemical and hormonal analyses (total antioxidant capacity [TAC], testosterone, folic lestimulating hormone [FSH] and luteinising hormone $[\mathrm{LH}])$. The circulating levels of testosterone, FSH and $\mathrm{LH}$ were determined according to the method of (Maruyama, 1987). TAC was determined according to (Koracevic and Koracevic, 2001).

Determination of the Gonadosomatic Index:

The body weight of each rat was determined immediately before sacrificing. After sacrifice and dissection, the testes were removed, and individual testes were weighed to determine the gonadosomatic index.
Tissue Sampling for Biochemical Analysis

Immediately after weighing the genitalia, each testis was homogenised for the biochemical analysis of antioxidant enzymes, including superoxide dismutase activity (SOD) , glutathione activity (GSH) were determined according to (Nishikimi, et al. 1972), and (Beutler, et al. 1963), respectively.

Statistical analysis:

The obtained data were statistically analyzed using computerized SPSS (Statistic Program Sigmastat, Statistical Soft-Ware, SAS Institute, Cary, NC). Effects of different treatments were analyzed by one way ANOVA (Analysis of variance) test using Duncan's multiple range test and $\mathrm{p}<0.05$ was used to indicate significance between different groups as described by (Snedecor and Cochran 1967).

\section{RESULTS\& DISCUSSION}

The radical scavenging activity of ginseng samples 
under study is shown in Table (1), the scavenging activity of ginseng extract at concentration of $2 \mathrm{mg}, 1.5$, 1.0 and $0.5 \mathrm{mg}$ were (96.06\%),(90.43\%),(87.46) and $(59.73 \%)$ respectively. Ginseng extract has high antioxidant activity which has been known not to be expressed by a single ingredient, but rather a synergistic effect involving several compounds (Parker et al. 2010) and (Kalleny et al. 2012).

Data presented in

Table (2) illustrated that individually, ginseng extract yielded identified constituents of polyphenolic compounds. The amount of phenolic contents, expressed as $\mathrm{g}$ of gallic acid equivalents per 100 $\mathrm{g}$ of ginseng.

The highest consisting of gallic acid (160.54 mg $/ 100 \mathrm{~g})$, ginsenoside $(93.7 \mathrm{mg}$ /100g), acid polysaccharide (74.65 mg /100g), ascorbic acid (22.43 mg /100g), curcumin (12.54 mg /100g), followed by maltol (10.748 $\mathrm{mg} / 100 \mathrm{~g})$. On the other hand, phenolic compounds in the ethyl acetate extract of ginseng were found to be $1.15 \%$ cinnamic acid, $0.24 \%$ quercetin and $0.19 \%$ pcoumaric acid by HPLC (Hwang et al. 2006). In general, phenolic compounds including p- coumaric acid, vanillic acid and ferulic acid have been reported to play an important role in the antioxidant activity of ginseng (Liu et al. 2002).

Table (3) showed the effect of ginseng powder, extract, L.Carnitine and L.Carnitine with ginseng powder and extract compared with control group.

Data recorded in Table (3) illustrated that sodium valproate caused significant decrease in weight gain, feed intake and FER compared to control group. No significant difference in body weight gain, feed intake and FER between treated group rats consumed ginseng powder, extract, L. carnitine and their combination.

Results in Table (4) indicated that positive control group increased significantly in the serum $\mathrm{TC}$, TG, and 
LDL-c. While the levels of HDL-c was significantly lower compared to the negative control group. Within groups of treated rats with ginseng powder, extract, L.Carnitine and their combination (L.Carnitine with ginseng powder and extract) had the lowest significant serum TC, TG, and LDL-c compared to the positive control group. On the other hand, all treated groups with different consumed ginseng powder and extract had significantly higher of HDL-c compared with those of the positive control group. According to (Nofer et al. 2002) and (Joo, 2013) who reported that ginseng saponin reduced blood cholesterol concentration by increasing cholesterol secretion through bile acid synthesis. (Yokozawa et al., 1985) reported that the blood cholesterol content decreased by promoting LDL receptor synthesis, contrary to our results.

From these results in Table (5), it could observe that there was significant improvement in uric acid, urea and creatinine on long term treatment with ginseng powder and extract, L.Carnitine with ginseng powder and extract against sodium valproate as the positive control group. Uric acid, creatinine, and urea level were significantly lowered in normal control group comparing with control (+ve) group. However treatment with ginseng powder and extract, L-Carntine with ginseng powder and extract significantly reduced these parameters compared to positive group. It appears from our results that high concentration of ginseng powder and extract were safe and improves renal functions. The increase in the level of these metabolites uric acid, creatinine and urea in nephrotoxic injury is a damage to one or both of the kidneys and results rats may suggest renal damage associated with sodium valproate may cause acute renal failure even after a dose.

The statistical data in Table (6) presented that, (+ve) control group showed significant increase in AST, 
ALT and ALP activity compared to (-ve) control group. The groups treated with ginseng powder and extract and L-Carnitine reduced the activity of AST and ALT , while significant decrease in AST, ALT and ALP by treated groups ginseng powder and extract and L-Carnitine with ginseng in comparing with (+ve) control group. The best result in AST with ginseng extract, ALT and ALP rats treated with L-Carnitine with ginseng powder and extract was appeared to the best results in our study.

Ginseng extract treated group significantly decreased the mean values of serum ALT, AST, and ALP enzymes, while was significantly increased nearly to the initial mean values of the control groups. This is attributed to that the anti carcinogenic mechanism of ginseng is partly involved in the elevation of the natural killer cell activity (Yun, et al. 1987)

As shown in Table (7), Oral administration of sodium valproate to male rats in dose $(500 \mathrm{mglkg}$ ) as (+ve) group significantly decreased the relative weights of testis compared to negative control male rats. Treated groups male rats consumed ginseng powder, extract, and mixture group (L-carnitine with ginseng powder and extract) had significant increase in weight of testis compared with the positive control group. There was a highly significant increase in the gonad somatic index of all experimental groups compared with the positive control group without significant differences between these treated groups. In addition, the results shown in Table (7) indicate that the sperm counts increased in all treated groups compared to the positive control group.

Results in table indicated that administration of sodium valproate in positive control group showed significant decrease in seurm testosterone (T), Follicle Stimulating Hormone (FSH) and luteinizing hormone ( $\mathrm{LH})$ compared to (-ve) control group. Ginseng treated group powder or extract, L-carnitinetreated group and L-carnitine 
with ginseng powder, extract, treated group significantly normalized serum testosterone, FSH and LH levels when compared with the positive control group.

These results were in agreement with (Fahim et al. 1982), who indicated that rats fed with $5 \%$ ginseng in their diet for 60 days showed significant increase in blood testosterone levels, whereas treatment with $1 \%$ ginseng had no effect (Wang et al. 2010). who found that ginseng (10 $\mathrm{mg} / \mathrm{kg}$ ), the major active constituent in ginseng, is responsible for the increase of serum testosterone levels. A clinical study that used of Asian ginseng extract showed to significant increase in the levels of plasma total and free testosterone, follicle stimulating hormone, and $\mathrm{LH}$, (Salvati et al. 1996).

Results in table (9) showed that oral administration of sodium valproate in positive control group showed significant decrease in total antioxidants, superoxide dismutase (SOD), glutathione $(\mathrm{GSH}), \quad$ and increase in malondialdehyde level compared to (-ve) control group. Ginseng treated group powder, extract, L-carnitinetreated group and ginseng $+\mathrm{L}$ carnitine-treated group enhanced the active of testicular total antioxidants, (SOD), malondialdehyde and (GSH) antioxidant enzymes as compared to positive control group (Kim and Park, 2003) reported that the activity of SOD and CAT increased by $31 \%$ and $24 \%$, respectively, when ginseng extract was fed for 8 weeks to humans. Jin and Chang (1993) stated that ginseng extract fed to mice increased the activity of SOD, peroxidase, and CAT.

\section{COCLUSION:}

In the present investigation, treatment with ginseng powder and extract combination with L-Carnitine has effectively alleviated most against sodium valproateinduced testicular toxicity and oxidative stress in male rats. Effects role of ginseng powder and extract attributed to increased testosterone and 


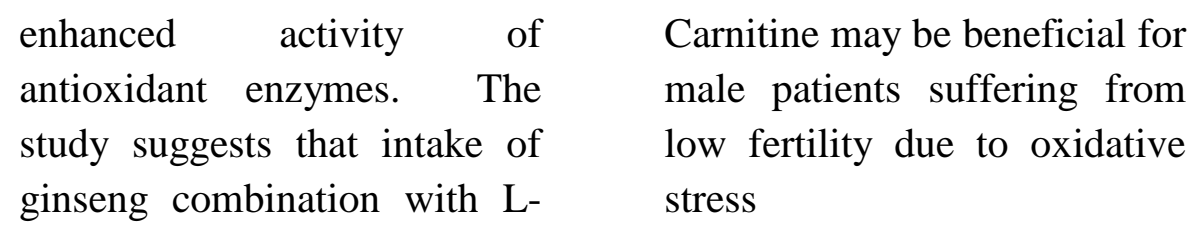

\section{REFRECENTS}

Attele, A.S.; Wu, J.A. and Yuan, C.S. (1999):

\section{Ginseng}

pharmacology:

Multiple constituents and multiple actions. Biochem. Pharmacol., 58, 1685-93.

Bairy, L.; Paul, V. and Rao Y.(2010):

Reproductive toxicity of sodium valproate in male rats. Indian $\mathrm{J}$ Pharmacol, 42(2): 904.

Bartels, H.; Bohemer, M. and Heirli, C. (1972):

Colorimetric kinetic method of creatinine. Clin. Chem. Acta., 37: 193.

Beutler, E.; Duron, O. and Kelly, M.B. (1963):

Determination of reduced glutathione in tissue homogenate. J. Lab Clin. Med. 61, 882.

Christensen, L.P.(2009):

Ginsenosides

chemistry,

biosynthesis, analysis, and potential health effects. Adv. Food Nutr. Res., 55, 199.

Fahim, M.S.; Fahim, Z. and Hafez, E.S. (1982):

Effect of Panax ginseng on testosterone level and prostate in male rats. Arch Androl. ;8:261-3.

Foster, D.W. (2004):

The role of thecarnitine system in human metabolism. Ann N YAcad. 
Fossati, P. and Prencipel, L. (1982):

Determination of triglycerides. Clinical Chemistry; 28: 20772078

Han, B.H.; Park, M.H.; Han, Y.N. and Shin, S.C. (1984):

Studies on the antioxidant

components of Korean ginseng Antifatigue active components. Yakhakhoe Chi , 28, 231-235.

Hwang, E.Y.; Kong, Y.H.; Lee, Y.C.; Kim, Y.C.; Yoo, K.M. and Choi, S.Y.(2006):

Comparison of phenolic compounds contents between white and red ginseng and their inhibitory effect on melanin biosynthesis. $\quad J$. Ginseng Res., 30, 8287.

Jin, C. and Chang, C.C. (1993):

The effects of red ginseng extracts on the superoxide dismutase, peroxidase and catalase activities in the liver of gamma ray irradiated mice. Korean $J$. Ginseng Sci. 17, 2934.

Joo, C.N. (2013):

The preventive effect of Korean ginseng saponins on aortic atheroma formation in prolonged cholesterol fed rabbits. In Korea Ginseng \& Tobacco Research Institute, Proceedings of the 3rd International Ginseng Symposium, Seoul, Korea; Korea Ginseng \& Tobacco Research Institute: Daejeon, Korea; pp. 27-36.

Kalleny, N.K.; Bahaa, N. and Elkabarity, R.H. (2012):

Synergistic effect of combined antioxidants on noise-induced acoustic trauma in adult guinea pigs. Audiological and Histological Study. Life Sci. J., 9, 640653. 
Kim, S.H. and Park, K.S.(2003):

Effects of Panax ginseng extract on lipid metabolism in Humans. Pharmacol. Res. 48, 511-513.

Kind, P. R. and King, E. J. (1954):

Estimation of alkaline phosphatase activity by determination of hydrolyzed phenol with aminoantipyrene.

Koracevic, and Koracevic, (2001):

Determination of TAC in serum. J. Clin. Pathol. 54, 356 - 361.

Liu, J.H.; Lee, C.S.; Leung, K.M.; Yan, Z.K.; Shen, B.H. and Jiang, Z.H.(2007):

Quantification of two polyacetylenes in radix ginseng and roots of related Panax species using a gas chromatography-mass spectrometric method.
J. Agric. Food Chem. 55, 8830-35.

Liu, Z.Q.; Luo, X.Y.; Sun, Y.X.; and Wang, Z.C. (2002):

Can ginsenosides protect human erythrocytes against free radical-induced hemolysis? Biochem. Biophys. Acta , 1572, 58-66.

Maruyama, Y. (1987):

Sex-steroid binding, plasma protein (SBP), testosterone, estradiol and DHEA in prepuberty and puberty.

Acta.Endocrinol. 114: 60-67.

Merfort, 1.; Wary, V.S.M. and Willuhan, G. (1997):

Flavonol triglycerides from seeds of Nigella Sativa. Phetochem. 46(2):359-363.

Mohamed, N.E. and Farghaly, A.A. (2009): Evaluation of the Protective Effect of L- 
Carnitine on Radiation

Induced Free Oxygen

Radicals

and

Genotoxicity in Male

Mice. Researcher. 1(6),

7-15.

Nishikimi, M.; Roa, N.A. and Yogi, K. ( 1972 ):

Determination of superoxide dismutase in tissue homogenate. Biochem. Bioph. Res.Common. 46, 849 -854 .

Nofer, J. R.; Kehrel, B. and Von Eckardstein, A. (2002):

HDL and arteriosclerosis:

Beyond reverse cholesterol transport. Atherosclerosis, 161, $1-16$.

Onem, G.; Aral, E. and Enli, Y. (2006):

Neuroprotective effects of Lcarnitine and vitamin $\mathrm{E}$ alone or in combination against ischemiareperfusion injury in rats. J Surg Res. 131, 124-130.

Patton, C. and Crouch, S. (1977):

Determination of serum urea enzymatically J. Ana. Chem.; 49 : 464 469.

Parker, T.L.; Miller, S.A.; Myers, L.E. and Engeseth, N.J.(2010):

Evaluation

of synergistic antioxidant potential of complex mixtures using oxygen radical absorbance capacity (ORAC) and electron paramagnetic resonance (EPR). J. Agric. Food Chem. 58, 209-217.

Reeves, P.G.; Nielson F.H. and Fahmy G.C.(1993):

Reports of the American Institute of Nutrition, Adhoc Wiling Committee on reformulation of the AIN 93. Rodent Diet. J. Nutri.; 123: 1939-51 
Reitman, S. and Frankel, S. (1957):

Estimation of serum alanine and aspartate aminotransferases. Clin .Path. Am. J.; 28: 5763.

Roeschlau, P.; Bernt, E. and Gruber, W. (1974):

Enzymatic colorimetric test with lipid clearing factor (LCF) .J. Clin.Chem. \& Clin. Biochem., 12:403-408.

Salvati, G.; Genovesi, G.; Marcellini, L.; Paolini, P.; Pepe, M. and Re, M. (1996):

Effects of Panax Ginseng C.A. Meyer saponins on male fertility. Panminerva Med. 38:249-54.

Shergis, J.L.; Zhang, A.L. and Xue, C.C.(2013):

Quality and risk of bias Panax ginseng randomized controlled trial: A review. Am. J. Chin. Med., 41, 231252.
Shun, W. C. (2010):

Department

of Applied Biology and Chemical Technology, The Hong Kong Polytechnic University, Hong Kong, China 2 State Key Laboratory of Chinese Medicine and Molecular Pharmacology, Shenzhen, China 41, 231-52.

Snedecor, G.W. and Cochran, W.G. (1967):

Statistical Methods. 7

Ed. the Iowa State University Press, Ames, Iowa, U.S.A.

Sun, Y. (2011):

Structure and biological activities of the polysaccharides from the leaves, roots and fruits of Panax ginseng C.A. Meyer: An overview. Carbohydr. Polym. 85, 490-9.

Wang, X., Chu, S., Qian, T., Chen, J., and Zhang, J. (2010): 


\section{Ginsenoside $\quad \operatorname{Rg} 1$ improves male copulatory behavior via nitric oxide/cyclic guanosine monophosphate pathway. J Med. ;7:743-50.}

Xie, J.T., McHendale S. and Yuan, C.S. (2005):

Ginseng and diabetes.

Am J Chin Med 33(3): 397404.

Yamaguchi, T., Takamura, H., Matoba, T. and Terao, J. (1998):

HPLC method for evaluation of the free radical-scavenging activity of foods by using 1, 1,-diphenyl-2picrylhydrazyl.

Bioscience

Biotechnology
Biochemistry, 62, 1201 $-4$

Yokozawa, T., Kobayashi, T., and Kawashima, $Y$. (1985):

Hyperlipemia improving effects of ginsenoside- $\mathrm{Rb} 2$ in cholesterol-fed rats. Chem. Pharm. Bull. Tokyo, 33, 722-729.

Yun,Y., Jo, S., Moon, H., and Yun,T. (1987):

Effect of red ginseng on natural killer cell activity in mice with lung adenoma induced by urethane and benzo (a) pyrene.Cancer Detect.Prev., I (suppl.) :301. 
Table (1): Scavenging effect (\%) of ginseng extract on (DPPH) radical.

\begin{tabular}{|c|c|c|c|c|}
\hline $\begin{array}{l}\text { ginseng } \\
\text { extract }\end{array}$ & $2 \mathrm{mg}$ & $1.5 \mathrm{mg}$ & $1.0 \mathrm{mg}$ & $0.5 \mathrm{mg}$ \\
\hline DPPH & $96.06 \pm 0.94$ & $90.43 \pm 1.69$ & $87.46 \pm 1.2$ & $59.73 \pm 3.07$ \\
\hline
\end{tabular}

Each value is the Mean \pm SD

Table (2): The concentration of phenolic compound in ginseng roots.

\begin{tabular}{|c|c|c|}
\hline phenolic compound & $\begin{array}{c}\text { RT min standard } \\
\text { retention } \\
\text { ( RT) } \text { min }\end{array}$ & $\begin{array}{c}\text { Mass } \\
(\mathbf{m g} / \mathbf{1 0 0 g})\end{array}$ \\
\hline Gallic acid & 2.2 & $\mathbf{1 6 0 . 5 4}$ \\
\hline Maltol & 3.0 & $\mathbf{1 0 . 7 4 8}$ \\
\hline Salicylic acid & 3.3 & $\mathbf{1 . 6 2 0}$ \\
\hline Vanillic acid & 4.0 & $\mathbf{1 . 0 2 0}$ \\
\hline p-Coumaric acid & 4.8 & $\mathbf{1 . 8 6 5}$ \\
\hline Curcumin & 5.2 & $\mathbf{1 2 . 5 4}$ \\
\hline L-Ascorbic acid & 5.7 & $\mathbf{2 2 . 4 3}$ \\
\hline Ginsenoside & 15.0 & $\mathbf{9 3 . 7}$ \\
\hline P-Hydroxycinnamic & 2.4 & $\mathbf{0 . 2 8}$ \\
\hline Pyrogallol & 7.9 & $\mathbf{0 . 6 4}$ \\
\hline Benzo-a-pyrene & 1.4 & $\mathbf{0 . 1 7}$ \\
\hline Acetylsalicylic acid & 10.0 & $\mathbf{0 . 3 5}$ \\
\hline Rosmerinic acid & 6.8 & $\mathbf{2 . 5 9}$ \\
\hline Lithospermic acid & 15.0 & $\mathbf{2 . 9 8}$ \\
\hline
\end{tabular}


Table (3): Effects of ginseng powder, extract, L-Carnitine and their combination Body weight gain, Feed intake and FER on rats intoxicated by sodium valproate

\begin{tabular}{|c|c|c|c|}
\hline Parameters & $\begin{array}{c}\text { Weight gain } \\
(\mathbf{g})\end{array}$ & $\begin{array}{c}\text { Feed intake } \\
(\mathbf{g} / \mathbf{d})\end{array}$ & FER \\
\hline Negative control & $101.76 \pm$ & $17.94 \pm$ & $0.097 \pm$ \\
& $8.11^{\mathrm{a}}$ & $2.20^{\mathrm{a}}$ & $0.03^{\mathrm{a}}$ \\
\hline Positive control & $55.64 \pm$ & $13.94 \pm$ & $0.063 \pm$ \\
& $8.11^{\mathrm{d}}$ & $2.20^{\mathrm{d}}$ & $0.06^{\mathrm{d}}$ \\
\hline Ginseng powder & $83.59 \pm$ & $16.80 \pm$ & $0.085 \pm$ \\
& $6.11^{\mathrm{c}}$ & $2.03^{\mathrm{a}}$ & $0.02^{\mathrm{c}}$ \\
\hline Ginseng extract & $85.13 \pm$ & $16.66^{\mathrm{c}}$ & $0.083 \pm$ \\
& $9.13^{\mathrm{c}}$ & $2.0^{\mathrm{a}}$ & $0.04^{\mathrm{c}}$ \\
\hline L-Carnitine & $88.77 \pm$ & $16.65 \pm$ & $0.085 \pm$ \\
& $9.17^{\mathrm{c}}$ & $2.21^{\mathrm{a}}$ & $0.03^{\mathrm{c}}$ \\
\hline L-Carnitine + & $93.44 \pm$ & $17.68 \pm$ & $0.091 \pm$ \\
Ginseng & $9.17^{\mathrm{b}}$ & $2.92^{\mathrm{a}}$ & $0.04^{\mathrm{b}}$ \\
\hline
\end{tabular}

Mean values in each column having different superscript $(a, b)$ are significant. Means with the same letter are insignificantly different. 
Table (4): Effects of ginseng powder, extract, L-Carnitine and their combination on lipid parameters on rats intoxicated by sodium valproate

\begin{tabular}{|c|c|c|c|c|}
\hline $\begin{array}{l}\text { Parameters } \\
\text { Groups }\end{array}$ & $\begin{array}{c}\text { TC } \\
\mathrm{mg} / \mathrm{dl}\end{array}$ & $\begin{array}{c}\text { TG } \\
\mathrm{mg} / \mathrm{dl}\end{array}$ & $\begin{array}{c}\text { HDL-c } \\
\mathrm{mg} / \mathrm{dl}\end{array}$ & $\begin{array}{l}\text { LDL-c } \\
\mathrm{mg} / \mathrm{dl}\end{array}$ \\
\hline $\begin{array}{c}\text { Negative } \\
\text { control }\end{array}$ & $\begin{array}{l}101.21 \pm \\
24.33^{\mathrm{a}}\end{array}$ & $\begin{array}{l}50.03 \pm \\
12.62^{\mathrm{a}}\end{array}$ & $\begin{array}{l}46.86 \pm \\
3.11^{\mathrm{a}}\end{array}$ & $\begin{array}{l}49.75 \pm \\
13.43^{\mathrm{a}}\end{array}$ \\
\hline Positive control & $\begin{array}{l}141.19 \pm \\
27.12^{d}\end{array}$ & $\begin{array}{l}80.43 \pm \\
14.82^{\text {a }}\end{array}$ & $\begin{array}{r}24.58 \pm \\
2.54^{\mathrm{a}}\end{array}$ & $\begin{array}{l}89.12 \pm \\
23.43^{\mathrm{a}}\end{array}$ \\
\hline $\begin{array}{l}\text { Ginseng } \\
\text { powder }\end{array}$ & $\begin{array}{l}116.27 \pm \\
26.54^{b}\end{array}$ & $\begin{array}{l}55.27 \pm \\
23.03^{b}\end{array}$ & $\begin{array}{l}34.97 \pm \\
2.66^{b}\end{array}$ & $\begin{array}{l}48.06 \pm \\
11.37^{b}\end{array}$ \\
\hline Ginseng extract & $\begin{array}{l}117.14 \pm \\
27.65^{b}\end{array}$ & $\begin{array}{l}56.17 \pm \\
24.34^{b}\end{array}$ & $\begin{array}{l}33.60 \pm \\
1.93^{\mathrm{b}}\end{array}$ & $\begin{array}{l}47.46 \pm \\
12.36^{\mathrm{b}}\end{array}$ \\
\hline L -Carnitine & $\begin{array}{l}125.48 \pm \\
4.28^{c}\end{array}$ & $\begin{array}{l}64.324 \pm \\
3.083^{c}\end{array}$ & $\begin{array}{l}32.02 \pm \\
2.76^{b}\end{array}$ & $\begin{array}{c}62.58 \pm \\
1.76^{\mathrm{c}}\end{array}$ \\
\hline $\begin{array}{c}\text { L.Carnitine } \\
\text { +Ginseng }\end{array}$ & $\begin{array}{c}103.27 \pm \\
4.54^{\mathrm{b}}\end{array}$ & $\begin{array}{l}56.194 \pm \\
3.456^{\mathrm{b}}\end{array}$ & $\begin{array}{l}31.97 \pm \\
2.75^{\mathrm{bc}}\end{array}$ & $\begin{array}{l}50.06 \pm \\
0.37^{c}\end{array}$ \\
\hline
\end{tabular}

Mean values in each column having different superscript $(a, b)$ are significant. Means with the same letter are insignificantly different. 
Table (5): Effects of ginseng powder, extract, L-Carnitine and their combination on uric acid, urea and creatinine on rats intoxicated by sodium valproate

\begin{tabular}{|c|c|c|c|}
\hline $\begin{array}{c}\text { Parameters } \\
\text { Groups }\end{array}$ & $\begin{array}{c}\text { Uric acid } \\
\mathbf{m g} / \mathbf{d l}\end{array}$ & $\begin{array}{c}\text { Creatinine } \\
\mathbf{m g} / \mathbf{d l}\end{array}$ & $\begin{array}{c}\text { Urea } \\
\mathbf{m g} / \mathbf{d l}\end{array}$ \\
\hline Negative control & $\begin{array}{c}1.53 \pm \\
0.78^{\mathrm{e}}\end{array}$ & $1.16 \pm$ & $27.88 \pm$ \\
& $3.18^{\mathrm{e}}$ & $4.72^{\mathrm{e}}$ \\
\hline Positive control & $0.52^{\mathrm{a}}$ & $5.62 \pm$ & $39.93 \pm$ \\
& $1.79 \pm$ & $3.87 \pm$ & $3.27^{\mathrm{a}}$ \\
\hline Ginseng powder & $0.72^{\mathrm{bc}}$ & $1.32^{\mathrm{b}}$ & $3.29^{\mathrm{b}}$ \\
\hline Ginseng extract & $1.82 \pm$ & $2.83 \pm$ & $31.17 \pm$ \\
& $0.57^{\mathrm{b}}$ & $1.25^{\mathrm{c}}$ & $3.59^{\mathrm{c}}$ \\
\hline L-Carnitine & $1.72 \pm$ & $2.72 \pm$ & $30.21 \pm$ \\
& $0.93^{\mathrm{c}}$ & $1.15^{\mathrm{c}}$ & $3.43^{\mathrm{d}}$ \\
\hline $\begin{array}{c}\text { L.Carnitine + } \\
\text { Ginseng }\end{array}$ & $1.65 \pm$ & $2.65 \pm$ & $31.90 \pm$ \\
\hline
\end{tabular}

Mean values in each column having different superscript (a, b) are significant. Means with the same letter are insignificantly different. 
Table (6): Effects of ginseng powder, extract, L-Carnitine and their combination on liver enzymes of rats intoxicated by sodium valproate

\begin{tabular}{|c|c|c|c|}
\hline Groups & $\begin{array}{c}\text { AST } \\
(\mathbf{I u} / \mathbf{l})\end{array}$ & $\begin{array}{c}\text { ALT } \\
(\mathbf{I u} / \mathbf{l})\end{array}$ & $\begin{array}{c}\text { ALP } \\
(\mathbf{I u} / \mathbf{l})\end{array}$ \\
\hline Negative control & $80.80 \pm$ & $65.21 \pm$ & $96.26 \pm$ \\
& $2.11^{\mathrm{a}}$ & $1.78^{\mathrm{a}}$ & $3.97^{\mathrm{a}}$ \\
\hline Positive control & $193.57 \pm$ & $142.86 \pm$ & $164.39 \pm$ \\
& $5.58^{\mathrm{d}}$ & $3.27^{\mathrm{d}}$ & $6.49^{\mathrm{d}}$ \\
\hline Ginseng powder & $116.86^{\mathrm{a}}$ & $74.76 \pm$ & $119.33 \pm$ \\
& $4.75^{\mathrm{b}}$ & $3.13^{\mathrm{b}}$ & $3.65^{\mathrm{b}}$ \\
\hline Ginseng extract & $103.08 \pm$ & $72.03 \pm$ & $124.74 \pm$ \\
& $4.28^{\mathrm{b}}$ & $3.43^{\mathrm{b}}$ & $5.649^{\mathrm{b}}$ \\
\hline L -Carnitine & $125.82 \pm$ & $80.75 \pm$ & $128.89 \pm$ \\
& $3.02^{\mathrm{b}}$ & $2.14^{\mathrm{c}}$ & $2.622^{\mathrm{b}}$ \\
\hline L.Carnitine & $118.08 \pm$ & $65.83 \pm$ & $114.74 \pm$ \\
+Ginseng & $4.28^{\mathrm{b}}$ & $3.43^{\mathrm{b}}$ & $5.649^{\mathrm{b}}$ \\
\hline
\end{tabular}

Mean values in each column having different superscript $(a, b)$ are significant. Means with the same letter are insignificantly different. 
Table (7): Effects of ginseng powder, extract, L-Carnitine and their combination on the testis weight, gonadosomatic iIndex $(\%)$, sperm count $(x$ 106/ML) on rats intoxicated by sodium valproate

\begin{tabular}{|c|c|c|c|}
\hline $\begin{array}{c}\text { Parameter } \\
\text { Groups }\end{array}$ & $\begin{array}{c}\text { Testis } \\
\text { weight } \\
(\mathbf{g} / \mathbf{1 0 0 g} \\
\mathbf{b . w t})\end{array}$ & $\begin{array}{c}\text { Gonado } \\
\text { somatic } \\
\text { index }\end{array}$ & $\begin{array}{c}\text { Sperm } \\
\text { number } \\
(\mathbf{1 0 6} / \mathbf{m l})\end{array}$ \\
\hline Negative control & $2.22 \pm$ & $0.68 \pm$ & $74.25 \pm$ \\
& $0.23^{\mathrm{a}}$ & $0.07^{\mathrm{c}}$ & $18.01^{\mathrm{a}}$ \\
\hline Positive contro & $1.1 \pm$ & 0.40 & $25 . .33 \pm$ \\
& $0.20^{\mathrm{d}}$ & $\pm 0.03^{\mathrm{d}}$ & $3.09^{\mathrm{d}}$ \\
\hline Ginseng powder & $1.85 \pm$ & $0.73 \pm$ & $59.33 \pm$ \\
& $0.20^{\mathrm{b}}$ & $0.07^{\mathrm{b}}$ & $24.09^{\mathrm{b}}$ \\
\hline Ginseng extract & $1.95 \pm$ & $0.72 \pm$ & $55.25 \pm$ \\
& $0.26^{\mathrm{b}}$ & $0.16^{\mathrm{b}}$ & $15.01^{\mathrm{b}}$ \\
\hline L -Carnitine & $1.55 \pm$ & $0.71 \pm$ & $45.42 \pm$ \\
& $0.14^{\mathrm{c}}$ & $0.06^{\mathrm{b}}$ & $20.01^{\mathrm{c}}$ \\
\hline L.Carnitine & $1.60 \pm$ & $0.73 \pm$ & $60.5 \pm$ \\
+Ginseng $^{\mathrm{c}}$ & $0.26^{\mathrm{c}}$ & $0.11^{\mathrm{b}}$ & $14.29^{\mathrm{b}}$ \\
\hline
\end{tabular}

Mean values in each column having different superscript $(a, b)$ are significant. Means with the same letter are insignificantly different. 
Table (8): Effects of ginseng powder, extract, L-Carnitine and their combination on sexual hormonal parameters on rats of rats intoxicated by sodium valproate

\begin{tabular}{|c|c|c|c|}
\hline \multicolumn{1}{|c|}{ Parameter } & $\mathbf{T}$ & $\mathbf{F S H}$ & $\mathbf{L H}$ \\
& & & \\
& $\mathbf{n g} / \mathbf{m L}$ & $\mathbf{n g} / \mathbf{m L}$ & $\mathbf{n g} / \mathbf{m L}$ \\
\hline Negative control & $26.2 \pm$ & $155.38 \pm$ & $4.9 \pm$ \\
& $1.7^{\mathrm{a}}$ & $6.75^{\mathrm{a}}$ & $0.76^{\mathrm{a}}$ \\
\hline Positive control & $16.03 \pm$ & $98.17 \pm$ & $1.8 \pm$ \\
& $2.01^{\mathrm{d}}$ & $7.55^{\mathrm{d}}$ & $1.16^{\mathrm{d}}$ \\
\hline Ginseng powder & $20.12 \pm$ & $118.98 \pm$ & $2.92 \pm$ \\
& $3.01^{\mathrm{b}}$ & $0.65^{\mathrm{b}}$ & $0.96^{\mathrm{c}}$ \\
\hline Ginseng extract & $19.33 \pm$ & $114.42 \pm$ & $2.54 \pm$ \\
& $14.81^{\mathrm{c}}$ & $0.80^{\mathrm{c}}$ & $0.52^{\mathrm{c}}$ \\
\hline L -Carnitine & $21.01 \pm$ & $116.60 \pm$ & $2.47 \pm$ \\
& $14.10^{\mathrm{b}}$ & $0.09^{\mathrm{c}}$ & $0.37^{\mathrm{c}}$ \\
\hline L.Carnitine & $25.81 \pm$ & $125.59 \pm$ & $3.8 \pm$ \\
+Ginseng & $19.64^{\mathrm{b}}$ & $0.80^{\mathrm{b}}$ & $0.96^{\mathrm{b}}$ \\
\hline
\end{tabular}

Mean values in each column having different superscript $(a, b)$ are significant. Means with the same letter are insignificantly different.

$\mathrm{T}$ : testosterone. FSH: Follicle Stimulating Hormone level

LH: Luteinizing hormone 
Table (9): Effects of ginseng powder, extract, L-Carnitine and their combination on antioxidant parameters on rats intoxicated by sodium valproate

\begin{tabular}{|c|c|c|c|c|}
\hline Parameters & $\begin{array}{c}\text { Total } \\
\text { Antioxidants } \\
\text { U/mg }\end{array}$ & $\begin{array}{c}\text { SOD } \\
\text { U/mg }\end{array}$ & $\begin{array}{c}\text { Malondial } \\
\text { dehyden } \\
\text { mol/L }\end{array}$ & $\begin{array}{c}\text { GSH } \\
\text { Mg/mgp } \\
\text { rotein }\end{array}$ \\
\hline $\begin{array}{c}\text { Negative } \\
\text { control }\end{array}$ & $3.38 \pm$ & $1.67 \pm$ & $6.47 \pm$ & $0.14 \pm$ \\
& $0.75^{\mathrm{a}}$ & $0.1^{\mathrm{a}}$ & $0.76^{\mathrm{d}}$ & $0.01^{\mathrm{a}}$ \\
\hline Positive control & $1.17 \pm$ & $0.33 \pm$ & $18.35 \pm$ & $0.10 \pm$ \\
& $0.55^{\mathrm{d}}$ & $0.01^{\mathrm{d}}$ & $1.16^{\mathrm{a}}$ & $0.01^{\mathrm{d}}$ \\
\hline Ginseng & $2.98 \pm$ & $1.0 \pm$ & $12.21 \pm$ & $0.15 \pm$ \\
powder & $0.65^{\mathrm{b}}$ & $0.04^{\mathrm{b}}$ & $0.96^{\mathrm{c}}$ & $0.04^{\mathrm{a}}$ \\
\hline Ginseng extract & $2.58 \pm$ & $1.2 \pm$ & $11.37 \pm$ & $0.13 \pm$ \\
& $0.80^{\mathrm{b}}$ & $0.06^{\mathrm{b}}$ & $0.52^{\mathrm{b}}$ & $0.06^{\mathrm{a}} \mathrm{b}$ \\
\hline L -Carnitine & $2.61 \pm$ & $0.90 \pm$ & $10.11 \pm$ & $0.12 \pm$ \\
& $0.09^{\mathrm{b}}$ & $1.10^{\mathrm{c}}$ & $0.37^{\mathrm{b}}$ & $1.10^{\mathrm{b}}$ \\
\hline L.Carnitine & $3.69 \pm$ & $1.33 \pm$ & $13.21 \pm$ & $0.18 \pm$ \\
+Ginseng $^{\mathrm{b}}$ & $1.80^{\mathrm{a}}{ }^{\mathrm{b}}$ & $0.08^{\mathrm{a}}{ }^{\mathrm{b}}$ & $0.96^{\mathrm{c}}$ & $0.08^{\mathrm{a}} \mathrm{b}$ \\
\hline
\end{tabular}

Mean values in each column having different superscript $(a, b)$ are significant. Means with the same letter are insignificantly different. 


\section{تأثير الجينسنج (باناكس الجينسنج) ضد تسمم

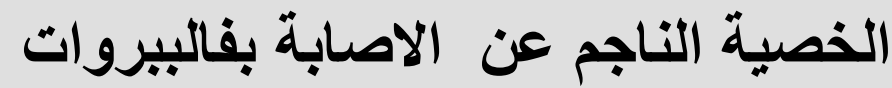 الصوديوم في ذكور الجرذان}

\section{لبنى أحمد شلباية}

قسم الاقتصاد المنزلي - كلية التربية النوعية -جامعة المنصورة

\section{الملخص العربي}

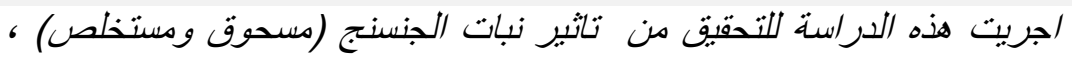

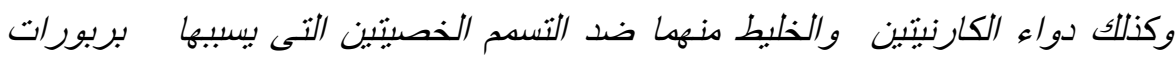

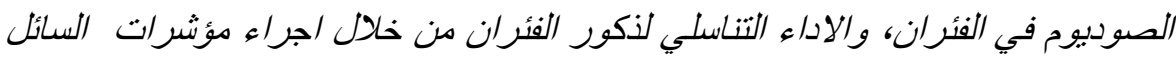

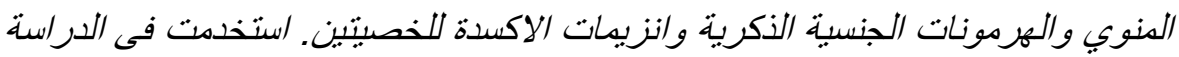

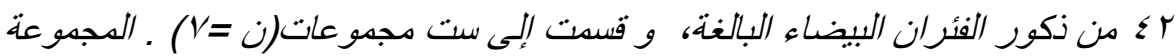

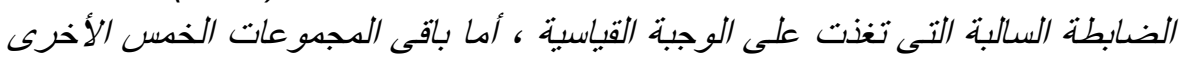

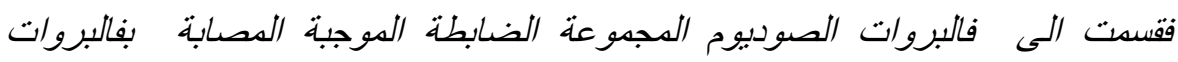

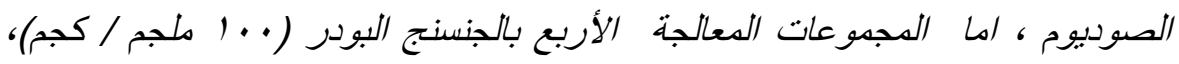

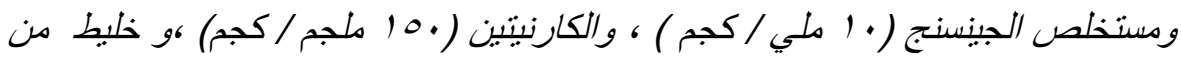

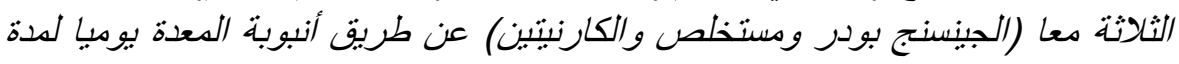

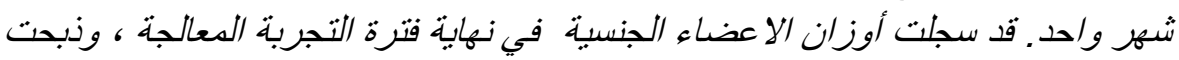

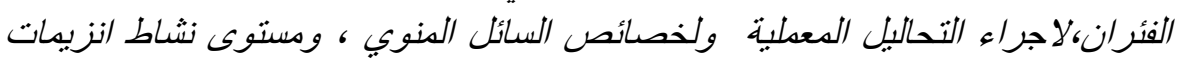

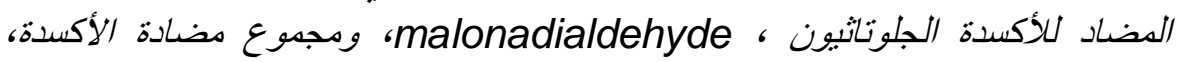

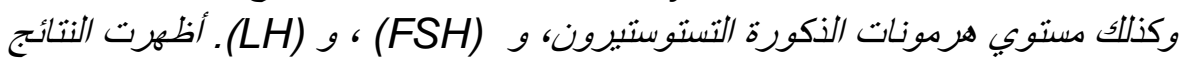

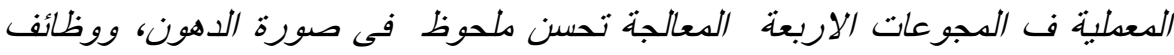

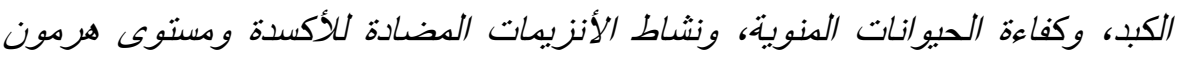

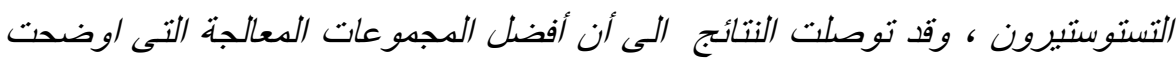

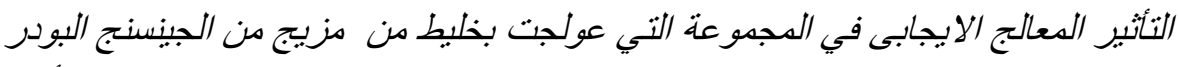

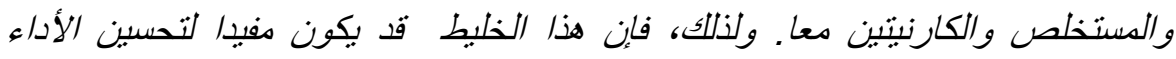
الجنسي لدى ذكور الفئران .

الكلمات المفتاحية: الجينسينج- ال كارنتين- فالبيروات الصوديوم- جرذان 